\title{
Akuntan Syariah Di Era Modern, Urgent Kah Di Indonesia?
}

\author{
Uun Dwi Al Muddatstsir dan \\ Early Ridho Kismawadi \\ Uundwi@gmail.com
}

\begin{abstract}
An accountant is responsible for serving Allah, society, profession, employer and customers, in performing the duties and services of profession diligently and correctly. Serving God through the work based on sharia, however, is the first priority. The Muslim community in Indonesia should be a model for the rise of a sharia-based system of work. Accountant sharia is the answer of all forms of work in the field of accounting that could respond to the challenges of the modern era. This is because it is appropriate with the rules that are taught in accordance with the beliefs of Moslem as the majority of people in Indonesia.
\end{abstract}

Keywords: Accounting, Accountant, and Sharia.

\begin{abstract}
ABSTRAK
Akuntan bertanggung jawab untuk melayani Allah, masyarakat, profesi, atasan, langganan, dalam menjalankan tugas dan pelayanan profesi dengan tekun dan benar. Tapi yang lebih penting adalah melayani Tuhan melalui pekerjaan berdasarkan syariah. Masyarakat Muslim Indonesia seharusnya menjadi model terhadap bangkitnya sistem pekerjaan berdasarkan syariah. Akuntan syariah adalah jawaban dari segala bentuk pekerjaan di bidang akuntansi yang bisa merespon tantangan zaman modern karena sesuai dengan peraturan yang diajarkan serta sesuai dengan kepercayaan umat Muslim yang merupakan mayoritas masyarakat di Indonesia.
\end{abstract}

Kata kunci: Akuntansi, Akuntan, dan Syariah

\section{PENDAHULUAN}

Dari sisi ilmu pengetahuan, Akuntansi adalah ilmu yang mencoba mengkonversi bukti dan data menjadi informasi dengan cara melakukan pengukuran atas berbagai transaksi dan dikelompokkan dalam account, perkiraan atau pos keuangan seperti aktiva, utang, modal, hasil, biaya, dan laba. Kaidah Akuntansi dalam konsep Syariah Islam dapat didefinisikan sebagai 
kumpulan dasar-dasar hukum yang baku dan permanen, yang disimpulkan dari sumber-sumber Syariah Islam dan dipergunakan sebagai aturan oleh seorang akuntan dalam pekerjaannya, baik dalam pembukuan, analisis, pengukuran, pemaparan, maupun penjelasan, dan menjadi pijakan dalam menjelaskan suatu kejadian atau peristiwa.

Hampir seluruh akuntansi Indonesia merupakan pengaruh dari Barat.Akuntansi konvensional (Barat) di Indonesia bahkan telah diadaptasi tanpa perubahan berarti.Hal ini dapat dilihat dari sistem pendidikan, standar, dan praktik akuntansidi lingkungan bisnis.Kurikulum, materi dan teori yang diajarkan di Indonesia adalah akuntansi pro Barat. Semua standard akuntansi berinduk pada landasan teoritis dan teknologi akuntansi IASC (International Accounting Standards Committee). Dunia bisnis juga tidak kalah, semua aktivitas dan system akuntansi juga diarahkan untuk memakai acuan akuntansi Barat.

Copeland skandal keuangan yang terjadi pada beberapa perusahaan besar dunia disebabkan kegagalan penerapan etika pada profesi auditor dan akuntan. Bahkan lima belas tahun yang lalu beliau pernah memberikan pandangan pada para partner dari Deloitte \& Touche, bahwa ancaman terbesar bagi profesi akuntan publik adalah kemungkinan kehilangan konsensus dalam masyarakat kita mengenai standar etika yang berlaku. Karena auditor sangat bergantung pada kejujuran penyajian laporan keuangan dari klien, dan pada etika dan kompetensi dalam menjalankan profesinya (Reni,2006).

Dalam dunia sekuler sumber kekuatan etika itu adalah berdasarkan rasio atau pemikiran manusia. Sehingga komitmen untuk penegakannya hanya terletak pada komitmen professional. Sedangkan dalam Islam, etika profesi akan dipaksa oleh syariat yang sumbernya dari Allah SWT. Akuntan dan auditor lembaga keuangan syariah wajib memenuhi kode etik yang bersumber 
dari ajaran Islam dan kode etik yang telah di tetapkan oleh standar audit lainya yang tidak bertentangan dengan prinsip syariah (Harahap, 2008).

Akuntansi dalam perspektif syariah Islam berkembang, seiring dengan perkembangan populasi penduduk muslim dan bank syariah di negeri ini, akuntansi juga akan terkena dampaknya. Hal ini sangat mungkin karena bentuk akuntansi itu sendiri di satu sisi sangat dipengaruhi lingkungan, di sisi yang lain setelah akuntansi dibentuk oleh lingkungannya, akuntansi akan mempengaruhi lingkungannya. Hal ini peran akuntan sangat besar dalam melakukan pengembangan ilmu akuntansi syariah dan mengawal akuntansi yang berbasis syariah Islam dalam tataran implementasinya. Perkembangan Akuntansi Syariah di Indonesia dilatarbelakangi oleh perkembangan lembaga keuangan syariah. Di Indonesia banyak bermunculan lembaga-lembaga keuangan yang berbasis syariah mengingat banyaknya masyarakat yang beragama Islam.

Namun demikian muncul kekhawatiran bahwa akuntansi syariah tidak berjalan dengan maksimal karena dukungan dari dunia pendidikan masih minim untuk mendidik para akuntan untuk berbasis syariah. Para pegawai bank syariah kebanyak adalah berlatar pendididikan non syariah. Ini akan memicu ketidak konsistenan antara harapan masyarakat terhadap peran akuntan syariah di negara yang islam mendominasi di dalam nya. Akuntan non syariah tidak memiliki dasar untuk menjalankan profesionalitas nya karena tidak pernah di ajarkan prinsip- prinsip syariah kecuali di berikan pelatihan yang cukup. Oleh karena itu penting nya pendidikan terkait akuntan syariah sudah saat nyalah semua pihak untuk mengutamakan pendidikan akuntansi berbasis syariah di bandingkan non syariah.

\section{Akuntan syariah}

Menjadi seorang akuntan yang taat syariah Islam adalah sebuah life choice. Akuntansi syariah yang telah berkembang menjadi alternatif bagi seorang calon akuntan sebagai sebuah lahan pekerjaan yang memilki keunikan 
tersendiri karena berbeda dengan pekerjaan lain. Namun choice tersebut sangat dipengaruhi oleh persepsi dan interpretasi yang terbangun dalam benak calon akuntan. Manusia selalu mengatur tingkah lakunya (termasuk pilihan-pilihannya) di dalam kehidupan sesuai dengan pemahaman (persepsi) yang dimilikinya (kariyoto, 2013), akuntan syariah lebih mengedepankan aspek keagamaan dalam setiap pengambilan keputusan bukan hanyaa demi kepentingan keuntungan individu atau organisasi. Akuntan berbasis syariah di harapka memiliki perilaku lebih baik di bandingkan akuntan konvesional karena akuntan syariah memiliki dasar pemikiran sejalan dengan pemikiran islam bahwa mengharamkan segala bentuk kecurangan dan ketidak adilan. Akuntan syariah akan memiliki spiritual lebih baik dibandingkan akuntan syariah. Namu pendidikan terhadap akuntan syariah di indonesia masih termarginalkan karena masih kurang nya lembaga pendidikan universitas yang memiliki jurusan akuntansi syariah atau ekonomi islam, namun belakangan ini dunia pendidikan mulai peka akan semua itu dan banyak bermunculan kampus-kampus yang menawarkan pendidikan syariah namum hanya beberapa mata ajar yang berbasis syariah dan masih mengajarkan aspek syariah. Sebuah kedok syariah yang belum murni.

Melihat mayoritas masyarakat Indonesia yang memeluk agama Islam, sebaiknya sistem akuntansi yang banyak diterapkan adalah sistem Akuntansi Syariah yang sesuai dengan keyakinan mayoritas mayarakat indonesia. Karena sistem akuntansi tersebut sesuai dengan syariah-syariah agama Islam yang di anut oleh mayoritas masyarakat di indonesia.

\section{Aspek-aspek yang harus dapat di terapkan akuntan syariah}

Dalam menjalankan praktik sebagai akuntan yang berbasis syariah, para akuntan harus memiliki aspek-aspek yang harus di laksanakan agar bisa menghasilkan laporan dan keputusan akuntansi yang bermanfaat serta sejalan dengan kaidah agama islam. Berikut beberapa aspke yang harus di taati oleh akuntan syariah. 


\section{- Integritas}

Islam menempatkan integritas sebagai nilai tertinggi yang memandu seluruh perilakunya. Islam juga menilai perlunya kemampuan, kompetensi dan kualifikasi tertentu untuk melaksanakan suatu kewajiban. Dalam Al-Qur'an surat Al-Qashash ayat 26 disebutkan bahwa:

"sesungguhnya orang yang paling baik yang kamu ambil untuk bekerja

(pada kita) adalah orang yang kuat lagi dapat dipercaya".

Integritas adalah adalah konsistensi dan keteguhan yang tak tergoyahkan dalam menjunjung tinggi nilai-nilai luhur dan keyakinan. Selama ini integritas seseorang dalam pekerjaan sering tergoyahkan karena kepentingan individu atau kepentingan suatu golongan yang menjadikan seseorang tidak mampu menghadapi tekanan untuk mempertahankan integritas nya.

\section{- Prinsip kekhalifahan manusia di bumi}

Allah berfirman:" Aku akan menciptakan Khalifah di bumi" (AlBaqarah:30), Ini berarti manusia dipercayakan untuk membangun dan memakmurkan bumi -Nya ini. Kekhalifahan ini didasarkan pada prinsip yang menyatakan bahwa pemegang kekuasaan tertinggi di bumi ini adalah Allah SWT dan kepemilikan manusia terhadap kekayaan yang di bumi ini bukanlah tujuan akhir tetapi sebagai sarana untuk menjalani kehidupan dirinya, keluarganya dan masyarakat. Manusia harus memperhatikan perintah dan larangan Allah selaku pemilik semua yang ada di bumi ini dalam penggunaannya sebab manusia akan dimintai pertanggungjawaban bagaimana ia menggunakan kekayaan itu.

\section{- Keikhlasan}

Landasan ini berarti bahwa akuntan harus mencari keridhaan Allah dalam melaksanakan pekerjaannya bukan mencari nama. Pura-pura, hipokrit dan berbagai bentuk kepalsuan lainnya. Menjadi ikhlas berarti akuntan tidak perlu tunduk pada pengaruh atau tekanan luar tetapi harus berdasarkan komitmen agama, ibadah dalam melaksanakan fungsi professinya. Tugas 
professi harus bisa dikonversikan menjadi tugas ibadah. Jika hal ini bisa diwujudkan maka tugas akuntan menjadi bernilai ibadah dihadapan Allah SWT disamping tugas professi yang berdimensi material dan dunia.

Ketakwaan

Takwa adalah sikap ketakutan kepada Allah baik dalam keadaan tersembunyi maupun terang-terangan sebagai slaah satu cara untuk melindungi dari akibat negative dan perilaku yang bertentangan dari syariah khususnya dalam hal yang berkaitan dengan perilaku terhadap penggunaan kekayaan atau transaksi yang cenderung pada kezaliman dan hal lain yang tidak sesuai dengan syariah. ketakwaan akan dapat diwujudkan bila kita mematuhi semua perintah dan menjauhi larangan Allah SWT. Allah berfirman dalam Al-Quran:

"Hai-hai orang yang beriman bertakwalah kepada Allah dengan sebenarbenarnya takwa kepadanya (Ali-Imran: 102)

Kebenaran dan bekerja secara sempurana

Akuntan tidak harus membatasi dirinya hanya melakukan pekerjaanpekerjaan professi dan jabatannya tetapi juga harus berjuang untuk mencari dan menegakkan kebenaran dan kesempurnaan tugas professinya dengan melaksanakan semua tugas yang dibebankan kepadanya dengan sebaik-baik dan sesempurna mungkin. Hal ini tidak akan bisa direalisir terkecuali melalui kualifikasi akademik, pengalaman praktek, dan pemahaman serta pengalaman keagamaan yang diramu dalam pelaksanaan tugas professinya. Sebagaimana Allah berfirman:

“ Allah memerintahkan kamu berbuat adil dan berbuat baik"(An-Nahl: 90)

\section{- Takut kepada Allah dalam setiap hal}

Seorang muslim meyakini bahwa Allah selalu melihat dan menyaksikan semua tingkah laku hambany-Nya dan selalu menyadari dan mempertimbangkan setiap tingkah laku yang tidak disukai Allah. Ini berarti 
bahwa seorang akuntan/auditorharusberperilaku"takut"kepada Allah tanpa harus menunggu dan mempertimbangkan apakah orang lain atau atasannya setuju atau menyukainya. Sikap ini merupakan sensor diri sehingga ia mampu bertahan terus-menerus dair godaan yang berasal dari pekerjaan professinya. Allah berfirman:

“sesungguhnya Allah selalu menjaga dan mengawasi kamu” (An-Nisa 1).

Dalam melakukan pekerjaannya akuntan syariah harus bisa meyakini bahwa apapun yang dilakukan nya selalu mendapatkan pengawasan dari Allah dan akan ia pertanggung jawabkan kelak semua apa yang telah dilakukannnya. Akuntan harus senantiasa menghindari apapun bentuk pekerjaan yang dilarang oleh Allah.

\section{Dasar akuntansi syariah}

Kapitalisme telah merambah dan menjerat ke seluruh penjuru kehidupan manusia. Perilaku kita secara sadar atau tidak berada dalam pengaruh kapitalisme. Akuntansi modern yang dikatakan akuntansi Anglo Saxon tidak terlepas dari pengaruhnya untuk lebih memperkokoh kekuatan kapitalisme (Hardiwinoto, 2006). Wajah akuntansi yang dibentuk oleh kapitalisme mendistorsi informasi bagi para penggunanya untuk melakukan keputusan dan aktivitas ekonomi. Karena sering kita temui aspek pengakuan terjadi sebelum kenyataan terjadi yaitu lebih berbasis akrual(kejadian yang belum riil, seperti pendapatan bunga) dari pada berbasis kas (kejadian riil).

Dasar hukum dalam Akuntansi Syariah bersumber dari Al Quran, Sunah Nabwiyyah, ljma (kespakatan para ulama), Qiyas (persamaan suatu peristiwa tertentu, dan 'Uruf (adat kebiasaan) yang tidak bertentangan dengan Syariah Islam. Kaidah-kaidah Akuntansi Syariah, memiliki karakteristik khusus yang membedakan dari kaidah Akuntansi Konvensional. Kaidah-kaidah Akuntansi Syariah sesuai dengan norma-norma masyarakat islami, dan termasuk disiplin 
ilmu sosial yang berfungsi sebagai pelayan masyarakat pada tempat penerapan Akuntansi tersebut.

Dasar penerapan akuntan syariah telah di atur di dalam al-qur'an Harahap (2004: 26) akuntansi sebenarnya merupakan domain "muamalah" dalam kajian Islam. Artinya diserahkan kepada kemampuan akal pikiran manusia untuk mengembangkannya. Namun karena pentingnya permasalahan ini maka Allah SWT bahkan memberikannya tempat dalam kitab suci Al-Qur'an, Al-Baqarah ayat 282 Ayat ini sebagai lambang komoditi ekonomi yang mempunyai sifat akuntansi yang dapat dianalogkan dengan "double entry", dan menggambarkan angka keseimbangan atau neraca.

Pada dasarnya kondisi lingkungan yang sebenarnya menentukan jenis dan isi standar akuntansi. Kebutuhan akan standar akuntansi yang bercirikan Islam merupakan hal yang tidak dapat dipisahkan dari perkembangan ekonomi Islam. Munculnya kembali pemikiran-pemikiran tentang ekonomi Islam makin meningkatkan persatuan sesama muslim dalam kegiatan politik dan ekonomi dapat dikatakan sebagai kekuatan baru perkembangan ekonomi di negaranegara Islam termasuk Indonesia, (Hardiwinoto, 2006).

Perkembangan tersebut mengarah pada penciptaan lingkungan ekonomi dan pasar yang seragam sesuai dengan nilai-nilai Islam. Akibatnya pelaporan keuangan perusahaan di negara-negara Islam akan ditandai dengan kekuatan politik, ekonomi, sosial dan budaya yang berbeda dengan negaranegara barat. Oleh karena kekuatan tersebut mempengaruhi tujuan dan format pelaporan keuangan, kebutuhan untuk memiliki standar akuntansi yang bernapaskan Islam merupakan suatu keharusan langkah yang perlu dilakukan dalam menyusun standar akuntansi Islam (Hardiwinoto,2006). Langkah-langkah yang perlu dilakukan antara lain:

1.Membentuk dan mempraktekan sistem ekonomi Islam sehingga mempengaruhi tujuan laporan keuangan yang berkaitan dengan standar akuntansi. 
2.Laporan keuangan yang dihasilkan harus mampu meyakinkan pemakai laporan bahwa perusahaan telah melaksanakan kegiatannya sesuai dengan prinsip-prinsip Islam (Karim, 1990).

3.Kualitas informasi yang dihasilkan relevan dan dapat diuji kebenarannya, tepat waktu dan karakteristik lain seperti yang diterapkan di negara barat yang konsisten dengan tiga hal pokok yaitu: Keadilan, kebenaran, dan kejujuran.

4.Kriteria pangakuan untuk masing-masing elemen pelaporan keuangan disajikan sesuai dengan syariat Islam. Wacana Akuntansi Syari'ah walau masih dalam tatanan konsep tapi sudah bisa digunakan untuk berbagai aktivitas ekonomi. Dan seterusnya dapat menjadi tatanan yang lebih praktis.

\section{Perbedaan akuntansi syariah dan konvensional}

Sedangkan perbedaannya, menurut (Syahatah, 2004), dalam buku Pokok-Pokok Pikiran Akuntansi Islam, antara lain terdapat pada hal-hal sebagai berikut:

1) Para ahli akuntansi modern berbeda pendapat dalam cara menentukan nilai atau harga untuk melindungi modal pokok, dan juga hingga saat ini apa yang dimaksud dengan modal pokok (kapital) belum ditentukan. Sedangkan konsep Islam menerapkan konsep penilaian berdasarkan nilai tukar yang berlaku, dengan tujuan melindungi modal pokok dari segi kemampuan produksi di masa yang akan datang dalam ruang lingkup perusahaan yang kontinuitas;

2) Modal dalam konsep Akuntansi Konvensional terbagi menjadi dua bagian, yaitu modal tetap (aktiva tetap) dan modal yang beredar (aktiva lancar), sedangkan di dalam konsep Islam barang-barang pokok dibagi menjadi harta berupa uang (cash) dan harta berupa barang (stock), selanjutnya barang dibagi menjadi barang milik dan barang dagang; 
3) Dalam konsep Islam, mata uang seperti emas, perak, dan barang lain yang sama kedudukannya, bukanlah tujuan dari segalanya, melainkan hanya sebagai perantara untuk pengukuran dan penentuan nilai atau harga, atau sebagi sumber harga atau nilai;

4) Konsep konvensional mempraktekan teori pencadangan dan ketelitian dari menanggung semua kerugian dalam perhitungan, serta mengenyampingkan laba yang bersifat mungkin, sedangkan konsep Islam sangat memperhatikan hal itu dengan cara penentuan nilai atau harga dengan berdasarkan nilai tukar yang berlaku serta membentuk cadangan untuk kemungkinan bahaya dan resiko;

5) Konsep konvensional menerapkan prinsip laba universal, mencakup laba dagang, modal pokok, transaksi, dan juga uang dari sumber yang haram, sedangkan dalam konsep Islam dibedakan antara laba dari aktivitas pokok dan laba yang berasal dari kapital (modal pokok) dengan yang berasal dari transaksi, juga wajib menjelaskan pendapatan dari sumber yang haram jika ada, dan berusaha menghindari serta menyalurkan pada tempat-tempat yang telah ditentukan oleh para ulama fiqih. Laba dari sumber yang haram tidak boleh dibagi untuk mitra usaha atau dicampurkan pada pokok modal;

6) Konsep konvensional menerapkan prinsip bahwa laba itu hanya ada ketika adanya jual-beli, sedangkan konsep Islam memakai kaidah bahwa laba itu akan ada ketika adanya perkembangan dan pertambahan pada nilai barang, baik yang telah terjual maupun yang belum. Akan tetapi, jual beli adalah suatu keharusan untuk menyatakan laba, dan laba tidak boleh dibagi sebelum nyata laba itu diperoleh.

\section{Prospek Akuntansi Syariah}

Dalam penilaian Global Islamic Financial Report (GIFR) tahun 2011, Indonesia menduduki urutan keempat negara yang memiliki potensi dan kondusif dalam pengembangan industri keuangan syariah setelah Iran, Malaysia dan Saudi Arabia(Grafik 1). 


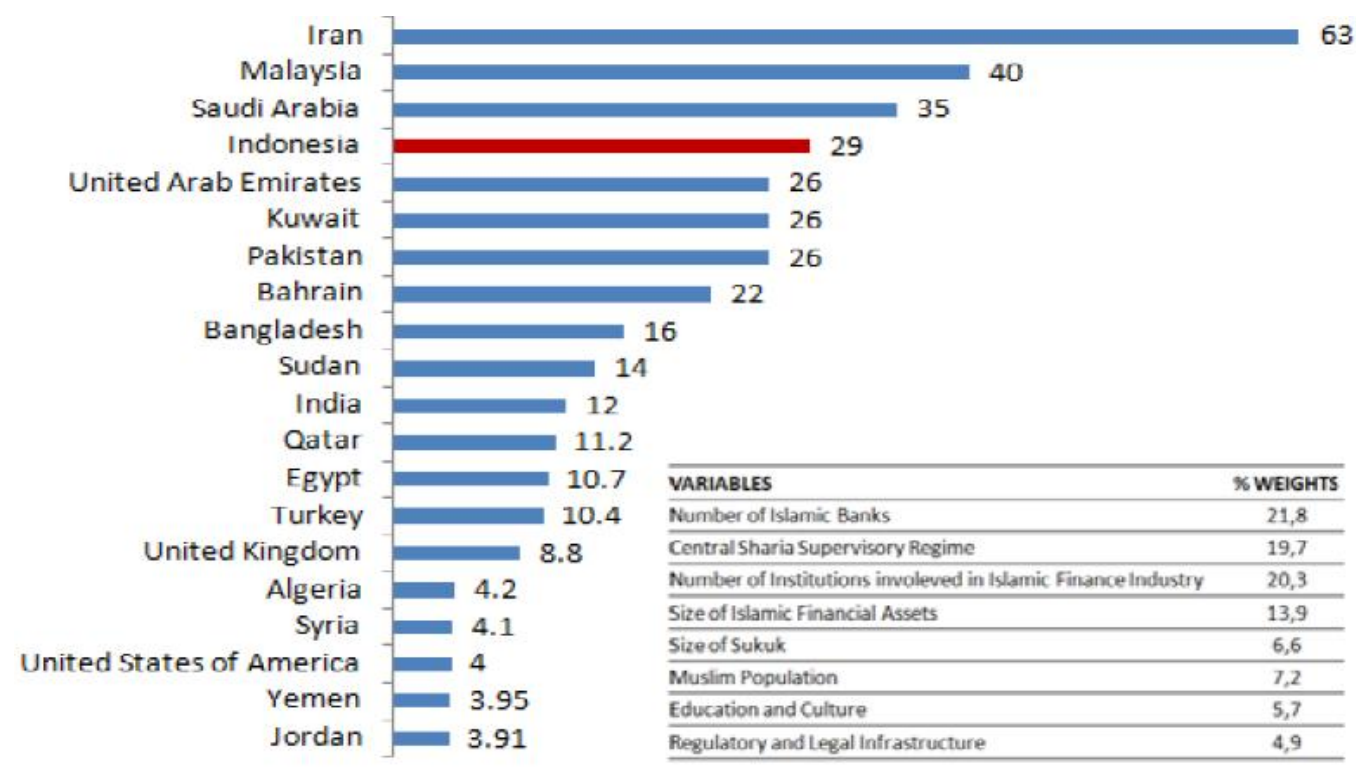

Grafik 1. Islamic Finance Country Index (IFCl, 2011)

Dengan melihat beberapa aspek dalam penghitungan indeks, seperti jumlah bank syariah, jumlah lembaga keuangan non-bank syariah, maupun ukuran aset keuangan syariah yang memiliki bobot terbesar, maka Indonesia diproyeksikan akan menduduki peringkat pertama dalam beberapa tahun ke depan. Optimisme ini sejalan dengan laju ekspansi kelembagaan dan akselerasi pertumbuhan aset perbankan syariah yang sangat tinggi, ditambah dengan volume penerbitansukuk yang terus meningkat (Alamsyah, 2012).

Seiring dengan perkembangan lembaga bisnis maupun non bisnis yang berlandaskan syariah, maka kebutuhan terhadap akuntansi syariah akan terus ada. Akuntansi syariah yang bersifat praktis untuk memenuhi kebutuhan transaksi entitas akan terus berkembang dengan menyeimbangkan disiplin ilmu akuntansi dengan landasan syar'i transaksi. Seiring dengan meningkatnya kesadaran umat Islam dalam melaksanakannya agama Islam dan pemenuhan pandangan bahwa aspek muamalah Islam bersifat universal, penggunaan maqasid asy syariah akan semakin luas dalam pengembangan akuntansi syariah yang applicable dan sesuai dengan ajaran Islam.

Hingga tahun 2014 hanya sekitar 54 orang yang memiliki Sertifikasi Akuntansi Syariah (SAS) yang dikeluarkan oleh Ikatan Akuntan Indonesia (IAI, 
2013). Dan akuntan publik yang dapat mengaudit LKS berdasarkan data yang dikeluarkan Otoritas Jasa Keuangan (OJK) baru berjumlah sekitar 30 KAP. Ini mengindentifikasikan bahwa akuntan syariah masih sangat kurang di indonesia. Peran pemerintah dan pihak akademisi sangat di butuhkan untuk melahirkan akuntan-akuntan syariah masa depan. Akuntan syariah merupakan pekerjaan yang melakukan segala kegiatan nya berdasarkan ajaran islam untuk menegakkan aturan ekonomi islami

Akuntansi secara syariah dijalankan untuk menciptakan iklim pekerjaanyang baik danlepas dari praktik kecurangan. akuntansi berdasarkan syariah di negeri ini mulai tampaktumbuh. Pertumbuhan itu tampak jelas pada sektor perbankan dimana mulai bertumbuhnya perbankan syariah di indonesia.

Menurut (Alim, 2011) dalam melakukan akuntansi atau seleksi tafsir qur'an dan hadis menjadi landasan teori akuntansi sehingga menjadi akuntansi syariah. oleh karena intu paradigma berfikir tauhid menjadi syarat mutlak. paradigma berfikir tauhid penting dalam islamisasi akuntan dan atau rekonstruksi akuntan syariah. tanpa itu maka akan mungkin menghasilkan teori-teori akuntansi yang hanya mengatas namakan syariah.

\section{Simpulan}

Akuntansi syariah sejatinya telah di atur dalam Al-qur'an sebelum para ilmuan membuat standar terkait akuntansi, namun masih kurang peka nya masyarakat islam terhadap peran akuntan syariah menjadikan akuntansi syariah terasa di kucilkan di negara yang di dominasi oleh umat muslim, walaupun usaha bisnis semakin banyak yang mulai beralih ke peradaban syariah namun masih banyak yang mengira semua itu hanya kedok semata karena meraka belum menerapkan konsep syariah yang sempurna seakan masih setengah-setengan, akuntansi dan akuntan syariah menjadi penting karena semua di pertanggung jawabkan bukan hanya kepada atasan atau 
pihak manajeman, akuntan syariah memaham kaidah-kaidah agama islam dan akan sadar jika melakukan perilaku menyimpang bukan hanya saja mendapatkan hukuman dari atasan namun juga akan mempertanggung jawabkan perilaku nya di hadapan Allah swt.

Diharapkan kepada organisasi yang menaungi akuntan syariah untuk bisa membuat peraturan dan kode etik kepada akuntan syariah secara formal karena akuntan syariah berbeda dengan akuntan konvensional dimana akuntan syariah lebih mementingkan prinsip keagamaan di bandingkan prinsip bisnis demi terciptanya bentuk keadilan dan kejujuran yang telah d ajarkan oleh islam. Oleh karena itu peran akuntan syariah menjadi sangat urgent untuk negara yang mayoritas muslim khususnya indonesia.

\section{DAFTAR PUSTAKA}

Alamsyah, Halim. 2012. Perkembangan dan Prospek Perbankan Syariah Indonesia:Tantangan Dalam Menyongsong MEA 2015. Disampaikan dalam Ceramah Ilmiah Ikatan Ahli Ekonomi Islam (IAEI), Milad ke-8 IAEI, 13 April 2012

Alim, Mohammad, N. 2011. Akuntansi Syariah Esensi, Konsepsi, Epistimologi, Dan Metodologi. Jurnal Investasi Vo, 7 No, 2 Hal 154-161.

Harahap, Sofyan S. 2002. Auditing Dalam Perspektif Islam, Pustaka Kuantum. Jakarta

Hardiwinoto. 2006. Standar Akuntansi Syari'ah (Paradigma Baru Sistem Akuntansi Di Indonesia)Value Added, Vol.2, No.2.

IAI. 2013.Pemegang SAS. Retrieved 03 23, 2014, from Sertifikasi Ikatan Akuntan Indonesia(SertifikasilAI):http://iaisertifikasi.blogspot.com/p/pemegangc psak.html?view=sna-pshot

Kasule, Omar Hasan. 2009. Epistemologi Islam Dan Integrasi IImu Pengetahuan Pada Universitas Islam: Epistemologi Islam Dan Proyek 
Reformasi Kurikulum. Makalah Pada Seminar Di Universitas Muhammadiyah Makasar 7 Februari 2009.

Kariyoto. 2013. Akuntansi Dalam Perspektif Syariah Islam. Jurnal Jibeka Volume 7 No 2.

Syahatah, Husein. 2004. Akuntansi Zakat: Panduan Praktis Penghitunganzakat. Kontemporer: Penerbit Pustaka Progressif. Jakarta.

Triyuwono, Iwan. 2006. Perspektif, Metodologi, Dan Teori Akuntansi Syariah. Pt. Raja Grafindo Persada. Jakarta. 